\title{
PENERAPAN METODE QUANTUM HIJAIYAH DALAM MENINGKATKAN KEMAMPUAN BACA AL-QURAN KOMUNITAS MUALLAF DI KALIMANTAN BARAT
}

\author{
SAMSUL HIDAYAT \\ Institut Agama Islam Negeri (IAIN) Pontianak \\ Email : camcul4@gmail.com
}

\begin{abstract}
:
This research is entitled: "Application of the Quantum Hijaiyah Method in Improving the Ability to Read the Koran of the Muslim Community in West Kalimantan". The purpose of this study is to guide the convert community (muallaf) to be able to read the Qur'an properly and correctly, equipping them with the ability to practice one of the teachings of Islam, namely to read the holy verses of the Qur'an in order to increase the spirit of converts in practicing Islamic teachings.The object of this research is the Muslim convert community (muallaf) in Senyabang Village, Sanggau District and the Muslim Community in Menjalin Village, Menjalin District, Landak Regency. This qualitative research model targets the social community as an active part of the research process, in order to increase the effectiveness of the data collection and analysis process to produce a recommendation that is truly beneficial for the improvement of the quality of their social life. The community-based research approach is more suitable if it uses an action research model, as applied research that requires dynamic and clinical trials. The results of the study were in the form of application a method of learning the Qur'an in an easier time with the Quantum Hijaiyah method. The training and development participants showed an increase in the mastery of reading hijaiyah letters and verses of the Qur'an during 19 hours of effective learning starting from pre-test, training and post-test activities. Increasing the reading ability of participants is proven by the results of tests and testimonials or acknowledgment from each participant who acknowledges the changes and improvement in the quality of reading the verses of the Qur'an.
\end{abstract}

Keywords: application, quantum hijaiyah, al-quran, muallaf.

\section{PENDAHULUAN}

Beberapa daerah di provinsi Kalimantan Barat termasuk area kritis karena faktor heterogenitas yang tinggi melalui pertemuan budaya dan keyakinan yang seringkali mengakibatkan banyaknya konversi agama dari pemeluk agama tertentu terutama antara pemeluk Islam ke Kristen atau sebaliknya. Dari beberapa kelompok atau desa yang melakukan konversi agama menjadi muslim (muallaf) dalam beberapa tahun terakhir adalah sekelompok warga suku Dayak di Desa Senyabang Kecamatan Balai Kabupaten Sanggau dan masyarakat Dayak di Desa Menjalin Kabupaten Landak Kalimantan Barat. 
Dengan banyaknya komunitas Dayak yang berpindah agama dari Kristen ke Islam, satu sisi menghadirkan kegembiraan bagi umat Islam karena bertambahnya komunitas muslim di daerah yang cukup berimbang pemeluk agamanya ini. Pada sisi lain terdapat kekhawatiran sekaligus tantangan bagi pimpinan umat Islam dalam melakukan pembinaan dan pendampingan pada muallaf agar aqidah dan keimanan mereka tetap terjaga dan pengamalan keagamaan mereka meningkat. Fakta membuktikan banyaknya kelompok masyarakat yang memeluk agama Islam, tidak diimbangi dengan pembinaan yang memadai dan maksimal sehingga tidak jarang para muallaf kembali lagi ke keyakinan awal mereka. ${ }^{1}$

Berbagai bentuk pembinaan keagamaan dapat dilakukan kepada para muallaf baik yang terkait dengan aqidah, ibadah dan muamalah. Pada pembinaan ibadah, salah satu bimbingan pokok bagi para muallaf adalah pengajaran baca tulis al-Quran sebagai modal dasar muallaf dalam memahami ajaran-ajaran Islam. Pembinaan baca al-Quran bagi muallaf Kalimantan Barat pada umumnya tidak berjalan baik, hal ini disebabkan kegiatan yang tidak berkesinambungan karena faktor minimnya tenaga pendakwah dan beratnya medan dakwah karena akses yang sulit dan jarak yang jauh dari perkotaan. Selain itu karena sulitnya menemukan metode baca al-Quran yang mudah dan cepat, sehingga sering ditemukan pembinaan muallaf terkait baca al-Quran terhenti di tengah jalan karena membutuhkan waktu yang lama sementara para pendakwah tidak memiliki waktu yang cukup dan kontinue dalam pembinaan.

Peneliti selaku akademisi di perguruan tinggi Islam khususnya di Institut Agama Islam Negeri (IAIN) Pontianak berkewajiban melakukan kegiatan Tri Dharma perguruan tinggi, salah satunya adalah melakukan penelitian-penelitian yang out put nya bisa dirasakan dan di impelementasikan langsung oleh masyarakat. Produk akademik dosen harus selaras dengan kebutuhan dasar masyarakat, terkait dengan pembinaan keagamaan maka salah satu kebutuhan masyarakat adalah pembinaan baca al-Quran baik bagi umat Islam yang mainstream maupun bagi pemeluk baru agama Islam (muallaf). Dalam sebuah desain pengabdian pada masyarakat, produk penelitian dosen ini dapat diterapkan di masyarakat sebagai upaya meningkatan sumber daya insani masyarakat di bidang keagamaan.

Peneliti menemukan metode cepat baca al-Quran sebagai bentuk solusi praktis bagi penanganan dan pemberantasan buta huruf al-Quran di masyarakat Islam termasuk bagi muallaf di Kalimantan Barat. Metode cepat baca al-Quran ini

${ }^{1}$ Samsul Hidayat, Pengembangan Metode Quantum Hijaiyah Sebagai Teknik Cepat Baca al-Quran pada Masyarakat Muallaf d Masjid Muhajirin Desa Senyabang Kecamatan Balai Kabupaten Sanggau Kalimantan Barat, dalam Maju Bersama, Jurnal Pendidikan Agama Islam, Volume 9 Edisi Desember 2017, h. 3. 
dinamai dengan metode Quantum Hijaiyah, sebuah metode yang dapat membuat seseorang bisa membaca al-Quran hanya dalam waktu 19 jam efektif. Metode ini diterapkan pada komunitas muallaf Desa Senyabang Kecamatan Balai Kabupaten Sanggau dan muallaf di desa Menjalin Kabupaten Landak selama 3 hari dengan total waktu 19 jam.

Metode Quantum Hijaiyah adalah sebuah teknik pembelajaran cepat yang memadukan kemampuan visualisasi dan imajinasi seseorang melalui metode asosiasi huruf dan gambar serta warna tertentu yang mudah dikenal dan dapat diingat dalam waktu yang lama, tanpa harus menghafal. Metode tanpa hafalan ini sangat cocok bagi usia dewasa termasuk muallaf karena menggunakan maksimalisasi fungsi otak kanan sehingga peserta dapat membaca al-Quran secara perlahan-lahan meskipin bagi mereka yang berusia lanjut.

Fenomena masih banyaknya masyarakat muslim di Kalimantan Barat khususnya dikalangan muallaf yang belum dapat membaca al-Quran menjadi keprihatinan tersendiri bagi peneliti yang berada di lingkungan perguruan tinggi Islam di Pontianak. Hal ini perlu dicarikan solusinya dengan memberikan pembinaan dan pengajaran Al-Quran yang lebih mudah dan lebih cepat dipahami oleh orang dewasa dimana kemampuan dan daya ingatnya cenderung menurun. Salah satu kegiatan strategis dalam rangka memberantas buta Al-Quran dilingkungan komunitas muallaf Kalimantan Barat adalah dengan melakukan penelitian terapan melalui bimbingan secara intensif agar pemahaman dan kemampuan baca Al-Quran masyarakat semakin baik.

Informasi yang Tim Peneliti dapatkan dalam penelitian pendahuluan, sudah ada guru mengaji yang menerapkan metode konvensional, tapi tidak pernah dalam waktu yang lama sehingga pembelajaran al-Quran tidak pernah tuntas. Selain itu belum ada pendakwah yang menerapkan metode cepat baca al-Quran. Dapat observasi, terdapat Lembaga Majelis Taklim Muallaf Kalimantan Barat yang sebenarnya telah melakukan berbagai cara dan kegiatan agar komunitas muallaf Desa Senyabang dan Desa Menjalin dapat segera mandiri dengan memiliki kemampuan baca al-Quran yang baik dan benar. Namun dari beberapa metode dan pengajar yang dihadirkan masih belum mampu memberikan perubahan kualitas baca al-Quran para muallaf, bahkan seringkali kembali lagi di kondisi awal, sama sekali tidak bisa membaca huruf-huruf hijaiyah. Hal ini bisa jadi disebabkan karena faktor usia komunitas yang rata-rata sudah di atas 30 tahun dan dengan kesibukan rutinitas kerja seperti menoreh karet seringkali menjadi penghambat komunitas dalam melakukan pembelajaran di rumah. Selain itu faktor lain yang menjadi penyebab gagal nya proses pembelajaran baca al-Quran di Desa Senyabang dan Desa Menjalin karena tidak adanya pendampingan dan kegiatan yang berkesinambungan mengingat jarak dan lokasi desa yang cukup jauh dari 
kota Pontianak sebagai pusat pendakwah atau guru agama di Kalimantan Barat.

Berdasarkan kondisi di atas, peneliti bermaksud melakukan penelitian terapan kepada komunitas muallaf di Desa Senyabang dan Desa Menjalin dalam bentuk penerapan teknik cepat baca al-Quran metode Quantum Hijaiyah yang ditemukan oleh Dr. Samsul Hidayat, MA, dosen Institut Agama Islam Negeri (IAIN) Pontianak sebagai solusi praktis dalam menangani dan memberantas buta huruf al-Quran di kalangan komunitas muallaf di Desa Senyabang Kecamatan Balai Kabupaten Sanggau dan Desa Menjalin Kecamatan Menjalin Kabupaten Sanggau Kalimantan Barat.

Kegiatan terapan dalam bentuk bimbingan cepat baca Al-Quran metode Quantum Hijaiyah dirancang khusus untuk usia dewasa yang sama sekali belum mengenal huruf-huruf hijaiyah dan cara membaca al-Quran. Dengan metode Quantum Hijaiyah, dalam 19 jam efektif pelatihan, umumnya peserta sudah dapat membaca al-Quran tingkat dasar atau perlahan-lahan namun sudah benar dalam kaidah baca al-Quran. Metode Quantum Hijaiyah merupakan teknik pembelajaran unik yang memadukan kemampuan visualisasi dan imajinasi peserta melalui sistem asosiasi dan pemahaman serta teknik memaksimalkan fungsi otak kanan sehingga membaca al-Quran jadi lebih cepat dan mudah meskipun bagi mereka yang sudah berumur lanjut.

\section{METODE PENELITIAN}

Penelitian terapan yang ditujukan pada komunitas muallaf Desa Senyabang Kecamatan Balai Kabupaten Sanggau dan muallaf Desa Menjalin Kecamatan Menjalin Kabupaten Landak ini menggunakan model penelitian berbasis komunitas (community based research). Pendekatan ini menghendaki adanya keterlibatan secara bersama-sama antara peneliti dan masyarakat, dalam seluruh kekuatan sumber daya yang dimiliki, selama proses penelitian sehingga menghasilkan kemanfaatan yang maksimal. ${ }^{2}$ Proses kegiatan penerapan metode Quantum Hijaiyah melibatkan pengurus Majelis Taklim Muallaf Kalimantan Barat baik dalam hal mengkoordinasikan peserta dan operasional kegiatan; mulai dari pemilihan peserta, pendampingan proses pembinaan sampai kepada evaluasi akhir dan pemantauan impelementasi hasil belajar melibatkan pihak luar dalam hal ini pengurus dan Pembina mullaf. Dengan model ini peneliti dapat menemukan rumusan solutif terhadap kemungkinan persoalan yang dihadapi selama kegiatan penerapan metode ini berlangsung. ${ }^{3}$ Penelitian berbasis komunitas ini banyak

2 Sarah Banks, Community Based Participatory Research A Guide to Ethical Principle and Practice, Center for Social Justice and Community Action, (Durham University: UK, 2012), h. 6.

3 Rena Pasick, DrPH, Geraldine Oliva, MD, MPH, Ellen Goldstein, MA, Tung Nguyen, MD, dalam Paula Fleisher, MA (Ed), Community-Engaged Research with Community Based Organization, Community Engagement Program. CTSI, (University of California: San Francisco, 2010), h. 4. 
berguna terutama dalam mengidentifikasi, memberikan dukungan dalam pengembangan sistem kehidupan sosial yang lebih baik, termasuk dalam melakukan upaya pencegahan atas kemungkinan persoalan yang dihadapi masyarakat.

Pelibatan Majelis Taklim Muallaf Kalimantan Barat dalam penelitian terapan ini memenuhi etika yang ditentukan dalam penelitian komunitas. ${ }^{4}$ Beberapa ketentuan yang dijadikan pedoman adalah mengutamakan rasa hormat kepada seluruh pihak yang dilibatkan dalam penelitian, kesamaan hak dalam partisipasi, saling mendorong dan mendukung dalam setiap pengambilan keputusan, saling menghargai dalam setiap proses kegiatan, mengutamakan kolegialitas dalam keragaman latar belakang pendidikan dan keahlian, serta mengedepankan integritas dan loyalitas demi suksesnya kegiatan yang dilakukan di masyarakat.

Lebih spesifik Dede Rosyada ${ }^{5}$ menggambarkan bahwa penelitian berbasis komunitas adalah model penelitian yang menjadikan target komunitas social sebagai pihak yang ikut terlibat secara aktif selama penelitian. Hal ini dilakukan dalam upaya meningkatkan efektifitas baik dalam proses pengumpulan data, dan analisis data guna menghasilkan produk kegiatan yang kemanfaatannya dapat direkomendasikan sebagai aktifitas yang berguna bagi perbaikan dan peningkatan kualitas kehidupan masyarakat.

Menurut Gregory ${ }^{6}$, untuk menerapkan secara utuh penelitian berbasis komunitas dapat menggunakan model action research, hal ini karena penelitian terapan memerlukan ujicoba dinamis dan klinis. Dalam proses ujicoba, kebanyakan data diuji secara kualitatif karena data yang diambil dapat saja berubah menyesuaikan fakta lapangan, sehingga pada tahap ini sering dilakukan evaluasi dan desain ulang untuk menemukan metode, model dan teknik yang paling tetap dan sesuai dengan kebutuhan masyarakat. Dalam hal ini studi tidak diarahkan untuk melakukan pencarian makna atau interpretasi pada data yang ada.

Peneliti sekaligus selaku penemu metode cepat baca al-Quran Quantum Hijaiyah melibatkan diri secara langsung dan menerapkan model pembelajaran cepat terhadap komunitas muallaf Desa Senyabang dan Desa Menjalin tersebut.

\footnotetext{
${ }^{4}$ Banks, Ibid, h. 8

5 Dede Rosyada Community Based Research CBR) Salah Satu Model Penelitian Akademik. http://www.uinjkt.ac.id/community-based-research-cbr-salah-satu-model-penelitian-akademik/ $\underline{(2016)}$

6 Gregory S. C. Hine, The importance of action research in teacher education programs, dalam Design, develop, evaluate: The core of the learn in environment. Proceedings of the 22nd Annual Teaching Learning Forum, 7-8 February 2013. Perth: Murdoch University. http://ctl.curtin.edu.au professional_development/conferences/tlf/tlf2013/refereed/hin e.html. (2013)
} 
Metode Quantum Hijaiyah ini dihasilkan dalam sebuah riset panjang, yaitu sekitar 3 tahun pada saat peneliti menyelesaikan program doktor di Universitas Islam Negeri (UIN) Sunan Kalijaga Yogyakarta. Metode cepat baca al-Quran ini merupakan telaah akademik peneliti dari beberapa kajian dan studi banding dari beberapa metode cepat al-Quran yang sebelumnya sudah banyak beredar dan berkembang d masyarakat. Beberapa aspek yang dapat dibandingkan dengan metode lain menyangkut teknik dan metode mempercepat pengenalan huruf serta mengingat huruf dalam waktu yang lebih lama tanpa harus dengan menghafal huruf, dan metode yang dapat di praktekkan atau diterapkan pada seorang lanjut usia. ${ }^{7}$

\section{HASIL PENELITIAN DAN PEMBAHASAN}

\section{Profil Muallaf Senyabang dan Menjalin}

Dalam penelitian pendahuluan (prelemenary research), Tim Peneliti menemukan bahwa komunitas muallaf Desa Senyabang dan Desa Menjalin selama ini dibina oleh Lembaga Majelis Taklim Muallaf Kalimantan Barat yang diketuai oleh Mohammad Damanhuri, S.Hi, SH, MH beralamat di Jalan Imam Bonjol Gang Mendawai Tengah No 44 Pontianak Tenggara Kalimantan Barat. Pada awalnya, kegiatan-kegiatan yang dilakukan oleh lembaga ini adalah melakukan pengajian, sunatan massal, bakti sosial, lalu sampai akhirnya membangun sebuah masjid yang baru diresmikan tahun 2015 oleh pemerintah setempat (Camat yang beragama Kristen) dengan nama Masjid Muhajirin Desa Senyabang. Sementara kegiatan pembinaan muallaf Desa Menjalin Landak dipusatkan di Masjid Nurul Yakin Menjalin Landak.

Masjid Muhajirin di Desa Senyabang Kecamatan Balai Kabupaten Sanggau dan Masjid Nurul Yakin Desa Menjalin Kabupaten Landak Kalimantan Barat merupakan beberapa masjid yang dikelola oleh muallaf dengan jamaah yang juga mayoritas muallaf. Saat ini komunitas muallaf di Masjid Muhajirin berjumlah 28 orang yang diketuai oleh bapak Yamin dan bapak Surya sebagai sekretaris, tidak termasuk jamaah masjid yang bukan muallaf. Dari 28 anggota komunitas muallaf, dalam survey pendahuluan menunjukkan belum ada satu anggotapun yang dapat membaca al-Quran dengan baik dan benar. Bahkan dalam sesi pre-test baca al-Quran, peneliti menemukan hampir $95 \%$ anggota muallaf masjid Muhajirin belum mengenal huruf hijaiyah dengan lengkap, baik, dan benar.

Pengelolaan masjid oleh para muallaf dilakukan dalam segala keterbatasan terutama dalam hal pendanaan dan sumber daya da'i atau penyuluh agama ditempat tersebut. Terkait dengan pembelajaran al-Quran bagi para muallaf, menurut pengakuan mereka sebenarnya pernah ada yang datang atau sebagian kecil pernah mendapatkan materi pendidikan baca al-Quran. Namun persoalan

${ }^{7}$ Samsul Hidayat, Pengembangan, Ibid, h. 5. 
yang dihadapi para muallaf adalah pendidikan baca al-Quran yang belum tuntas dan tidak ada pembinaan yang intensif dalam pembelajaran al-Quran. Akibatnya para muallaf belum ada yang benar-benar bisa membaca al-Quran dengan baik dan benar.

Anggota Komunitas Muallaf Masjid Muhajirin Desa Senyabang Kecamatan Balai Kabupaten Sanggau Kalimantan Barat yang dilatih dalam proses penerapan metode Quantum Hijaiyah berjumlah 28 orang, terdiri dari 5 orang laki-laki dan 23 muallaf perempuan. Para muallaf merupakan masyarakat lokal sebagian besar beretnik Dayak dengan tentang usia antara umur 25 sampai 60 tahun. Sementara komunitas muallaf di Masjid Nurul Yakin Desa Menjalin Kabupaten Landak di ketuai oleh Ibu Fatimah dengan 25 orang muallaf binaan, terdiri dari 24 wanita dan 1 pria dengan rentang usia antara 22 sampai 40 tahun. Dari observasi ditemukan hanya ada 2 orang muallaf yang sudah memiliki kemampuan dasar membaca ayat al-Quran dan selebihnya masih belum mengenal sama sekali huruf hijaiyah.

Desa Senyabang Kecamatan Balai Kabupaten Sanggau dan Desa Menjalin Kecamatan Menjalin Kabupaten Landak merupakan daerah dengan penduduk mayoritas beragama Kristen. Dalam kondisi desa yang jauh dari perkotaan, komunitas muallaf masjid Muhajirin Senyabang dan masjid Nurul Yakin Landak sangat jarang mendapatkan pembinaan rutin dari masyarakat atau organisasi keagamaan Islam baik dari daerah Sanggau dan Landak atau luar Sanggau dan Landak karena kabupaten ini diapit oleh kabupaten Bengkayang dan Sekadau yang juga mayoritas beragama Kristen.

Kegiatan penelitian dalam bentuk penerapan teknik cepat baca al-Quran di Desa Senyabang dan Desa Menjalin adalah kegiatan yang tepat dan strategis mengingat kondisi riil komunitas yang sangat membutuhkan bimbingan keagamaan setelah mereka memeluk agama Islam. Sejauh informasi yang peneliti dapatkan, para muallaf di Desa Senyabang dan Desa Menjalin sangat jarang mendapat bimbingan keagamaan termasuk praktek baca al-Quran mengingat minimnya pendakwah, guru atau pendidik yang mampu mengajarkan metode khusus bagi muallaf dalam belajar al-Quran. Pembelajaran al-Quran dengan metode konvensional kepada komunitas muallaf sejauh ini belum mampu meningkatkan kemampuan baca al-Quran para muallaf dengan baik dan maksimal.

Program pendampingan masyarakat dalam bentuk penerapan teknik cepat baca al-Quran di Desa Senyabang dan Desa Menjalin adalah kegiatan yang tepat dan strategis mengingat kondisi riil komunitas muallaf yang sangat membutuhkan bimbingan keagamaan setelah mereka memeluk agama Islam. Sejauh informasi yang Tim Peneliti dapatkan dalam penelitian pendahuluan (prelemenary research), 
para muallaf di Desa Senyabang dan Desa Menjalin sangat jarang mendapat bimbingan keagamaan termasuk praktek baca al-Quran mengingat minimnya pendakwah atau guru yang mau datang atau yang mampu mengajarkan metode khusus bagi muallaf dalam belajar al-Quran. Pembelajaran al-Quran dengan metode konvensional kepada komunitas muallaf sejauh ini dianggap belum mampu meningkatkan kemampuan baca al-Quran para muallaf dengan baik dan maksimal. Hal ini dapat dilihat dari banyaknya buku-buku atau modul baca alQuran di rak masjid Muhajirin dan Masjid Nurul Yakin bantuan masyarakat tapi tidak dipergunakan komunitas berhubung tidak ada yang bisa mengajarkan kepada mereka.

\section{Sekilas Tentang Quantum Hijaiyah}

Dalam upaya pencapaian tujuan pembelajaran, termasuk dalam proses pembelajaran al-Quran, sangat ditentukan oleh metode yang digunakan dalam pembelajaran tersebut. ${ }^{8}$ Metode juga merupakan sarana penyampaian materi dalam sebuah kurikulum. Efektif dan efisiennya proses penyampaian materi, ditentukan oleh metode yang tepat. Dengan menggunakan metode tertentu, maka cara yang ditempuh pendidik dalam melahirkan sebuah sistem pembelajaran yang menyenangkan dan mendukung sehingga melahirkan prestasi bagi anak didik. ${ }^{9}$

Akademisi dari UIN Syarif Hidayatullah Jakarta, Prof. Armai Arief 10 menyatakan bahwa keefektifan sangat diperlukan dalam setiap proses pemilihan dan penggunaan sebuah metode. Jika metode pembelajaran yang digunakan tidak efektif, maka akan menjadi penghambat kelancaran proses belajar mengajar sehingga banyak waktu dan tenaga yang akan terbuang sia-sia. Menurut Wina Sanjaya $^{11}$ metode yang tepat dapat mendukung pencapaian tujuan pembelajaran. Oleh sebab itu, metode yang diterapkan oleh pendidik akan fungsional dan berhasil guna jika mampu dipergunakan dalam mencapai tujuan pendidikan yang ditetapkan, termasuk dalam pembelajaran al-Quran.

Sejauh ini masyarakat muslim Indonesia mengenal beberapa metode cepat baca a-Quran dengan berbagai teknik pembelajaran dan ciri khas masing-masing penemunya seperti metode Metode An-Nur (Rosyadi, 1999), Metode QLC (Jakarta), Metode SMART (Surakarta), Metode Talaqi (Al Maliki, 2011), Metode Alhuda (Yahya, 2016), Metode Al-Kaustar (Yogyakarta), Metode al-Fatah (Mudhar, 2011) dan masih banyak metode cepat lainnya yang pada umumnya dilaksanaka di area dan waktu terbatas karena jarang yang bertahan lama. Metode

${ }^{8}$ Arif Hidayat. Cara Kilat Pandai Membaca Al-Qur'an. (Jakarta: PT. Buku Kita, 2011), h. 21.

9 Rusmono. Strategi Pembelajaran dengan Problem Based Learning Itu Perlu: Untuk Meningkatkan Profesionalitas Guru. (Bogor: Ghalia Indonesia, 2012), h. 24.

${ }^{10}$ Armai Arief. Pengantar Ilmu dan Metodologi Pendidikan Islam. (Jakarta: Ciputat Pers, 2002), h.39.

11 Wina Sanjaya. Strategi Pembelajaran Berorientasi Standar Proses Pendidikan. (Jakarta Kencana Prenada Media Group, 2007), h. 145. 
Quantum Hijaiyah menawarkan teknik pembelajaran Al-Qur'an yang berbeda, karena menggabungkan beberapa metode pembelajaan cepat seperti metode asosiasi, metode pemahaman dan teknik memaksimalkan fungsi otak kanan dengan memberdayakan kemampuan visualisasi dan imajinasi peserta sehingga membaca Al-Qur'an menjadi lebih mudah dan cepat, meskipun bagi usia lanjut. ${ }^{12}$

Jika dibandingkan dengan sistem belajar Al-Qur'an metode konvensional, maka metode Quantum Hijaiyah dapat membuat peserta puluhan kali lebih cepat dalam membaca Al-Qur'an. Hal ini karena selama ini teknik belajar Al-Qur'an dengan sistem lama kebanyakan menggunakan sistem hafalan (otak kiri) dan sima'an (mengikuti apa yang dibaca guru). Pada dasarnya belajar membaca AlQur'an itu hanya terdiri dari tiga tahapan: pertama, mengenal huruf hijaiyah. Penguasaan huruf mutlak diperlukan karena 90\% kunci keberhasilan membaca A1Qur'an berasal dari penguasaan huruf-huruf tersebut. Kedua, mengerti tandatanda baca dan tajwid dasar. Ketiga, membaca terus menerus dan berkesinambungan, inilah tahap yang paling menentukan dan disini diperlukan keistiqomahan serta semangat yang pantang menyerah.

Pada pembelajaran selama 19 jam, komunitas muallaf Masjid Muhajirin Desa Senyabang Sanggau dan Masjid Nurul Yakin Menjalin Landak akan diajarkan Metode Quantum Hijaiyah sebagai teknik cepat mengenali huruf hijaiyah, mengenal tanda baca dan tajwid dasar sehingga membaca Al-Qur'an menjadi lebih mudah karena metode ini menggabungkan model terbaru teknik pembacaan Al-Qur'an dengan memaksimalkan fungsi otak kanan (visualisasi, gambar dan warna) sehingga ayat-ayat Al-Qur'an lebih cepat diingat dan difahami. $^{13}$

Melalui penelitian terapan dalam bentuk bimbingan teknik cepat baca alQuran metode Quantum Hijaiyah, diharapkan akan terjadi perubahan semangat belajar dan peningkatan kemampuan baca al-Quran sehingga komunitas muallaf di Desa Senyabang dan Desa Menjalin dapat hidup beragama secara mandiri, dengan mempraktekkan amalan amalan keagamaan secara maksimal. Memiliki kemampuan baca al-Quran merupakan jendela bagi umat Islam untuk dapat menelaah, mengkaji dan mengamalkan kandungan al-Quran dengan lebih baik dan maksimal.

Atas dasar pertimbangan diatas, program pengabdian masyarakat berbasis terapan dan pendampingan ini menjadi penting dilakukan dalam upaya meningkatkan kemandirian dari komunitas muallaf di Desa Senyabang dan Desa Menjalin. Tim Peneliti juga berharap agar mitra Tim yaitu Lembaga Majlis Taklim

12 Samsul Hidayat, Pengembangan, Ibid, h. 9.

${ }^{13}$ Samsul Hidayat. Pengembangan, Ibid. h. 8. 
Muallaf Kalimantan Barat dapat terberdayakan dengan melanjutkan pembinaan dan pendampingan pembelajaran al-Quran metode Quantum Hijaiyah melalui metode yang telah diajarkan pada waktu berikutnya.

Penerapan teknik cepat baca al-Quran metode Quantum Hijaiyah akan didahului dengan pre- test terhadap seluruh peserta baca al-Quran dan post-test setelah kurikulum pembelajaran selesai diajarkan. Pada sesi pre-test setiap peserta satu persatu diminta untuk membaca huruf hijaiyah sesuai dengan kemampuan penyebutan hurufnya. Setiap peserta biasanya membaca huruf hijaiyah sesuai dengan metode yang pernah mereka pelajari sebelumnya. Setelah seluruh kemampuan baca peserta terpetakan, selanjutnya Tim peneliti akan melaksanakan proses pembinaan dengan total waktu 19 jam dan diakhiri dengan post test untuk mengukur tingkat keberhasilan.

Dalam menerapkan metode Quantum Hijaiyah, semua peserta diminta untuk meninggalkan seluruh metode belajar al-Quran yang pernah mereka pelajari sebelumnya. Hal ini karena terdapat beberapa perbedaan krusial teknik pembelajaran seluruh metode baca al-Quran yang selama ini ada di masyarakat dengan metode Quantum Hijaiyah, seperti dalam hal penyebutan huruf, visualisasi huruf, asosiasi huruf, urutan huruf dan pengelompokkan jenis huruf.

\section{Penerapan Pembelajaran Quantum Hijaiyah Pada Muallaf}

Pembelajaran metode Quantum Hijaiyah terdiri dari tiga tahap dengan menggunakan tiga modul. Modul pertama, materi pengenalan huruf hijaiyah dengan metode Quantum Hijaiyah. Modul kedua, materi berhubungan dengan lima tanda baca huruf dan prakteknya. Modul ketiga, materi tajwid dasar untuk mengenalkan kaidah baca huruf Arab dengan kategori dasar. Pada modul 1, peserta diperkenalkan dengan 28 huruf hijaiyah dengan asosiasi huruf bergambar dan berwarna. Ke dua puluh delapan huruf ini biasanya dapat dikuasai peserta dalam waktu 2.5 jam saja atau 150 menit.

Untuk membaca dan mengingat huruf-huruf hijaiyah metode Quantum Hijaiyah, berikut beberapa panduan yang harus diikuti agar hasil yang hendak dicapai dapat sesuai dengan target.

a. Praktekkan membaca huruf hijaiyah 5 (lima) huruf persesi (sekitar 5 menit). Jika sudah diingat dan dikuasai, dapat dilanjutkan dengan membaca 5 huruf berikutnya selama 5 menit. Pada tahap kedua langsung dapat disimulasi dengan menggabungkan total 10 huruf yang sudah dipelajari. Lakukan metode baca per lima huruf sambil melakukan simulasi per sesi yang telah dibuat.

b. Ketika hendak menyebut sebuah huruf, mulailah dengan membaca konsonan huruf dulu, baru sebutkan gambarnya. Misal ketika membaca huruf pertama bacalah: A, Anggar, lalu minta peserta untuk membacanya juga. Seterusnya lanjutkan dengan mambaca: B, Bibir, lalu minta peserta 
untuk membacanya juga. Selalu gunakan alat tunjuk atau bolpen agar peserta lebih fokus.

c. Simulasi huruf sebaiknya dilakukan secara berurut dari atas kebawah dan bawah ke atas, dan atau lakukan dengan cara acak. Terkadang penulis juga melakukan metode kejut, yaitu kadang-kadang diminta untuk membaca biasa, lalu tiba-tiba peserta diminta untuk membaca secara cepat.

d. Lakukan praktek membaca per lima huruf sesuai dengan tabel huruf yang ada di bawah. Huruf-huruf di susun berdasarkan kategori akhiran A dan O. Hal ini dilakukan setelah penulis mengevaluasi proses mengingat huruf antara yang berakhiran A (misal A, BA, TA dan seterusnya) ternyata lebih mudah dibanding huruf yang berakhiran $O$ (seperti Kho, Ro, Shod an seterusnya). Untuk membuat huruf-huruf tadi lebih mudah diingat, penulis membuat 2 (dua) kategori huruf, A dan $\mathrm{O}$, dimana huruf-huruf A penulis letakkan dibagian awal untuk di pelajari lebih dulu, setelah dikuasai semua baru dilanjutkan ke huruf-huruf konsonan $\mathrm{O}$ yang lebih sulit untuk diingat.

Berikut huruf-huruf hijaiyah yang telah di kelompokkan dan dimodifikasi dengan kategori $\mathrm{A}$ dan $\mathrm{O}$, dan diasosiasikan dengan gambar berwarna yang disesuaikan dengan konsonan huruf awal yang sama dengan nama gambarnya ${ }^{14}$ :

\section{Gambar 1}

Modifikasi Huruf Hijaiyah dalam Metode Quantum Hijaiyah
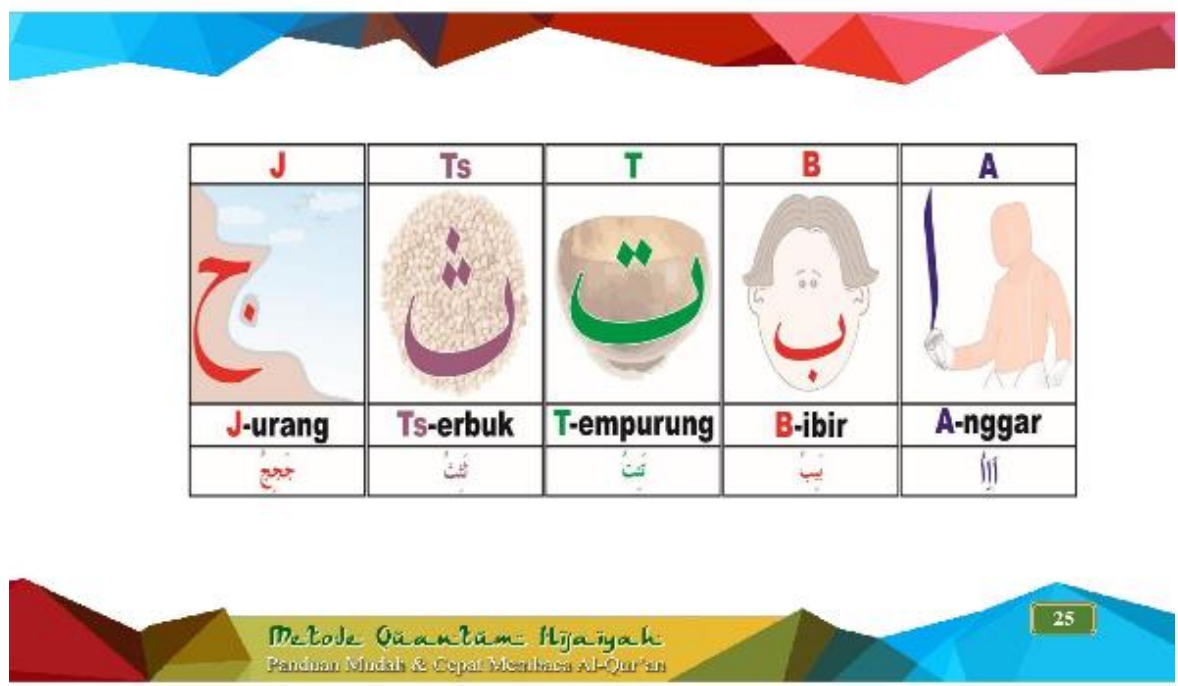

${ }^{14}$ Samsul Hidayat Quantum Hijaiyah; Panduan Mudah dan Cepat Membaca al-Quran (19 Jam Bisa Baca al-Quran). (Pontianak: IAIN Press, 2015), h. 29-34. 
Gambar 2

Asosiasi Huruf Hijaiyah melalui Benda yang Memiliki Kemiripan

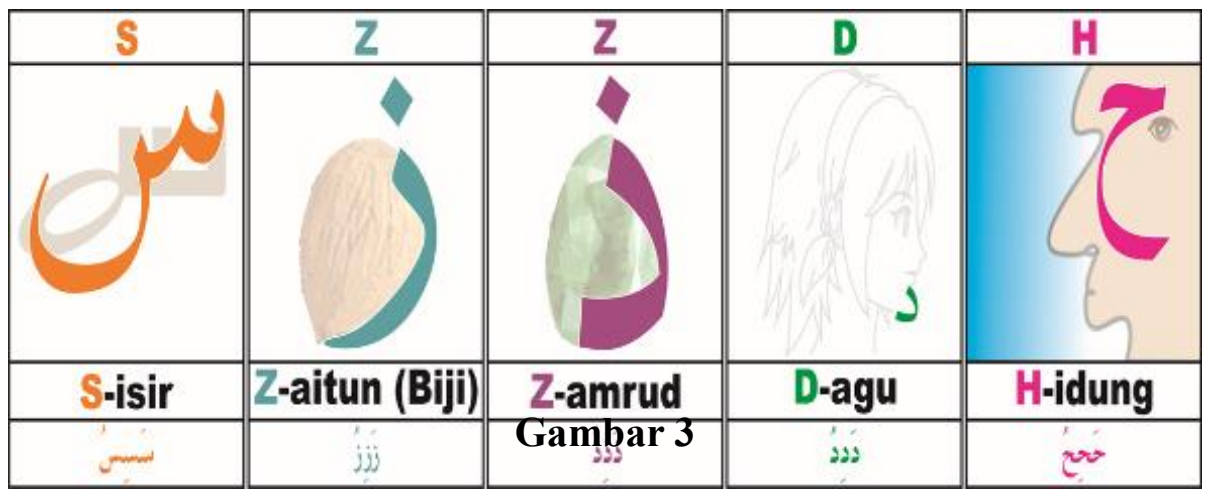

Pada tahap ini Peserta Sudah Diajari Tanda Baca Huruf (Fathah, Kasroh, Dhommah)

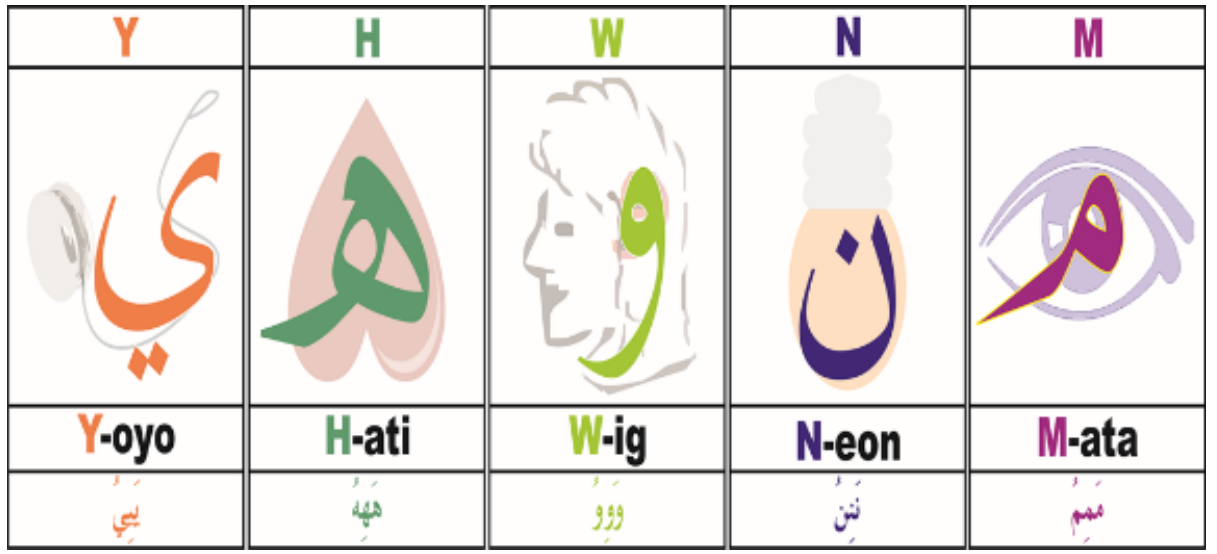

Gambar 4

Penentuan Huruf yang ber-akhiran baca $\mathrm{O}$ di urutan akhir

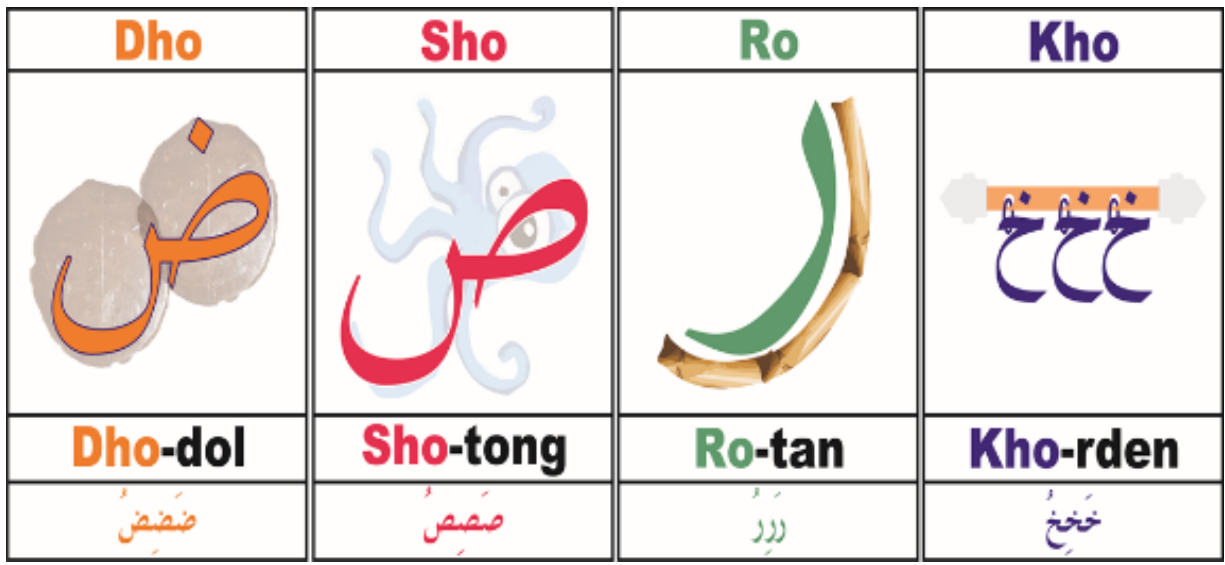

Pada proses pembelajaran modul 1, peserta diminta untuk melihat, membaca huruf-huruf yang telah dimodifikasi dalam kelompok huruf yang terdiri dari 5 huruf saja. Dalam waktu 5 menit peserta sudah harus menguasai 5 huruf 
tadi, dan begitu berikutnya. Pada modul 1, peserta sudah dapat mengenal 28 huruf hijaiyah hanya dalam waktu 2.5 jam. Pada sesi ini peserta dituntun untuk mengenal semua huruf hijaiyah tanpa melihat gambar, tapi langsung dikenalkan dengan semua huruf yang telah mereka pelajari. Adapun cara menguji kemampuan ingat peserta adalah dengan meminta mereka membaca seluruh huruf hijaiyah dengan cara mengacak semua huruf seperti melalui tabel di bawah ini ${ }^{15}$ :

Gambar 5

Lembar Post Test Modul 1

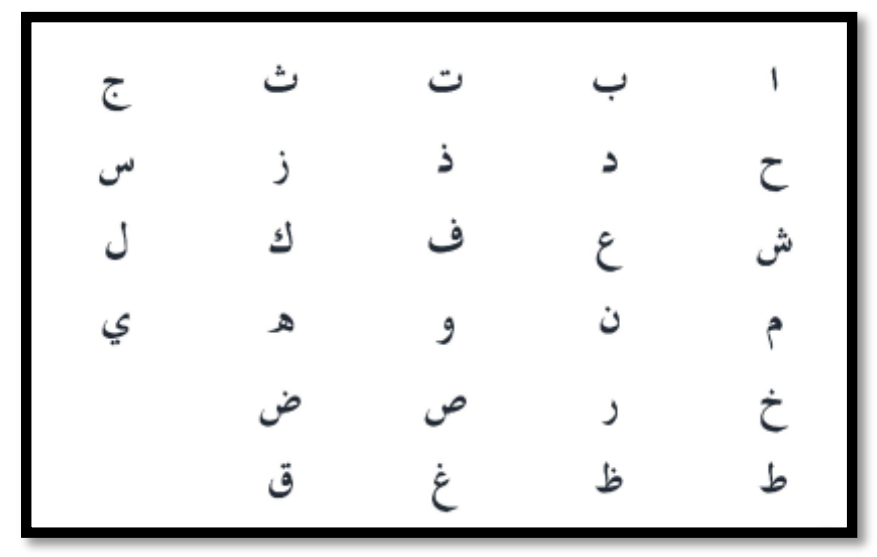

Lembar pre test huruf hijaiyah ini juga digunakan pada saat post test pada modul 1. Biasanya lembar ini digunakan pada saat peserta telah dikenalnya pada kelompok huruf, yaitu huruf 1-5, 6-10, 11-15, 16-20, 21-24, 25-28. Pada kelompok huruf 1-5 (A, B, T, Ts, J), peserta dilatih untuk menguasai huruf dalam waktu 25 menit, pada sesi menit terakhir, peserta diminta untuk membaca kelima huruf tadi dengan urut dan acak. Selanjutnya pada kelompok huruf 6-10 (H, D, Dz, Z, S), peserta kembali diminta untuk membaca huruf dan menyebut gambar huruf, lalu pada sesi akhir mereka diminta untuk membaca 10 huruf sekaligus baik secara urut maupun acak. Pada sesi acak, materi dapat diacak oleh mentor atau dilakukan simulasi, yaitu perwakilan murid yang maju ke depan memberikan pengarahan bagaimana cara membaca huruf-huruf yang sudah diajarkan tadi.

Pada modul 2, peserta dikenalkan beberapa tanda baca dalam huruf hijaiyah seperti fathah, kasroh, dhommah, tanwin, sukun, tasydid, berikut perubahan yang terjadi pada huruf saat pada posisi bersambung. Pada umumnya peserta mulai mengalami kesulitan pada saat memasuki materi huruf sambung. Namun dengan metode Quantum Hijaiyah, peserta sejak modul 1 sudah dikenalkan dengan ciri huruf dan perubahannya dalam posisi sambung.

Metode Quantum Hijaiyah menggunakan beberapa metode yang memudahkan peserta dalam mengenal 5 tanda baca huruf, meskipun dalam huruf

${ }^{15}$ Samsul Hidayat. Quantum, Ibid, h. 41. 
sambung. Salah satu cara yang memudahkan peserta diantaranya huruf-huruf yang akan menjadi penekanan diberi warna khusus. Peneliti mengingatkan agar peserta fokus pada huruf yang diwarnai karena huruf berwarna tadi adalah materi utama yang sedang dipelajari. Sambil memperhatikan terus menerus perubahan huruf saat dalam kondisi bersambung, peserta diminta untuk terus aktif membaca dengan bibir untuk membiasakan mulut mengucapkan huruf Arab. Beberapa peserta yang enggan untuk mengucapkan langsung huruf-huruf akan mengalami kendala pada proses belajar berikutnya. Metode Quantum Hijaiyah di design agar peserta terlibat aktif dalam pembelajaran.

Selain menggunakan tanda huruf berwarna, susunan contoh kata perkata diurut sedemikian rupa sesuai fokus bacaan, mulai dari awal, tengah dan akhir. Misal ketika memberi contoh pelajaran tanda baca huruf alif, peserta dikenalkan dengan 3 buah huruf alif yang berada di depan, tengah dan akhir dengan warna tertentu. Pada umumnya peserta akan sangat senang dan tidak menyangka ternyata membaca huruf-huruf hijaiyah dapat dilakukan dengan mudah dan cepat. Namun dalam setiap tahap pembelajaran, tentu saja semakin dalam materi yang disampaikan maka semakin tinggi kerumitannya. Hal ini terutama pada pembelajaran tanda baca tasydid. Peserta harus mendapatkan bimbingan dengan ekstra agar seluruh tanda baca huruf hijaiyah dapat dibaca dengan baik dan benar.

\section{Gambar 6}

Tanda Baca Fathah, Kasroh dan Dhammah

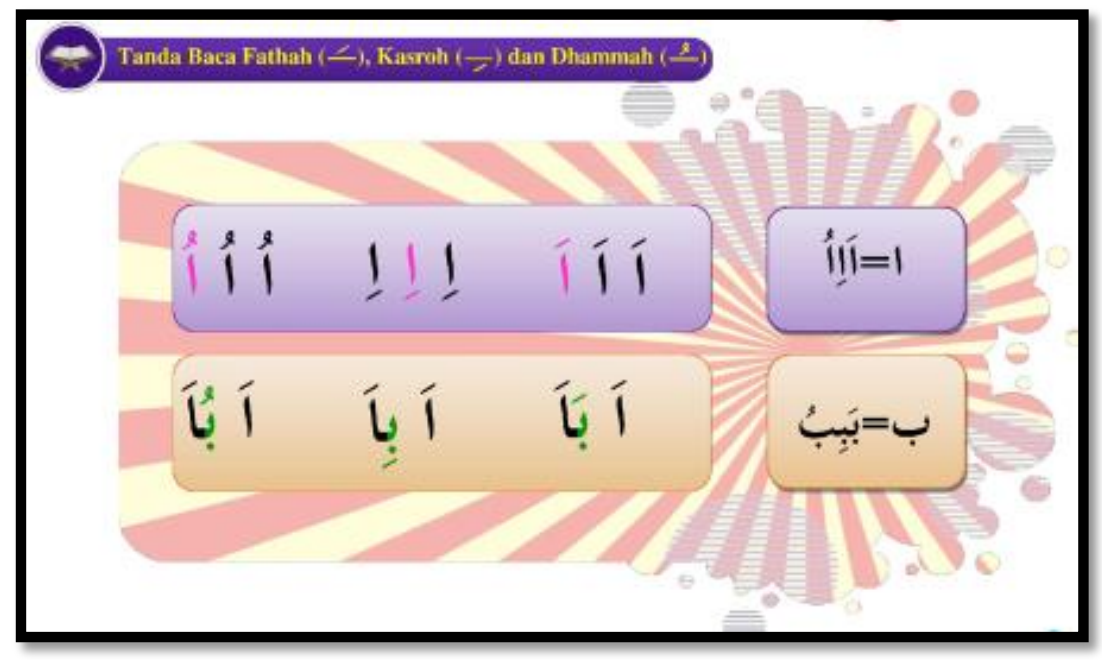

Peneliti melakukan penentuan sampel-sampel huruf berdasarkan urutan huruf yang dipelajari dari awal. Misalnya ketika yang diajarkan adalah materi A dan B maka sampel yang dibuat hanya seputar huruf A dan B. Jika materi yang diajarkan antara huruf $A$ dan $S$, maka seluruh sampel yang dibuat tidak keluar dari huruf-huruf yang sudah diajarkan yaitu hanya antara A dan S. ${ }^{16}$

${ }^{16}$ Samsul Hidayat. Quantum, Ibid. h. 46. 


\section{Gambar 7}

Tanda Baca Panjang/Mad, Fathah ( I ), Kasrah ( ب ) dan Dhommah ( و )

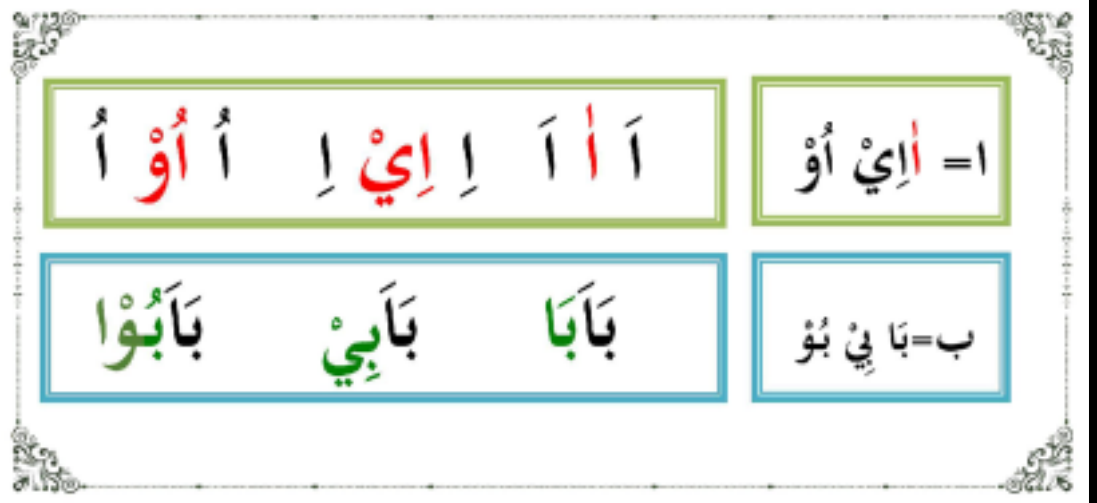

Tanda baca mad pada huruf dibuat berurutan dari tanda A atau alif, Y sukun dan $\mathrm{W}$ sukun. ${ }^{17}$ Dalam setiap sampel yang dibuat, ketiga tanda baca mad diberikan warna tertentu agar peserta lebih fokus dan mudah mengenal materi (Lihat gambar 7). Dalam prakteknya membaca huruf yang berwarna menjadi lebih menyenangkan dan tidak monoton.

\section{Gambar 8}

Peserta diminta menulis huruf dan membacanya

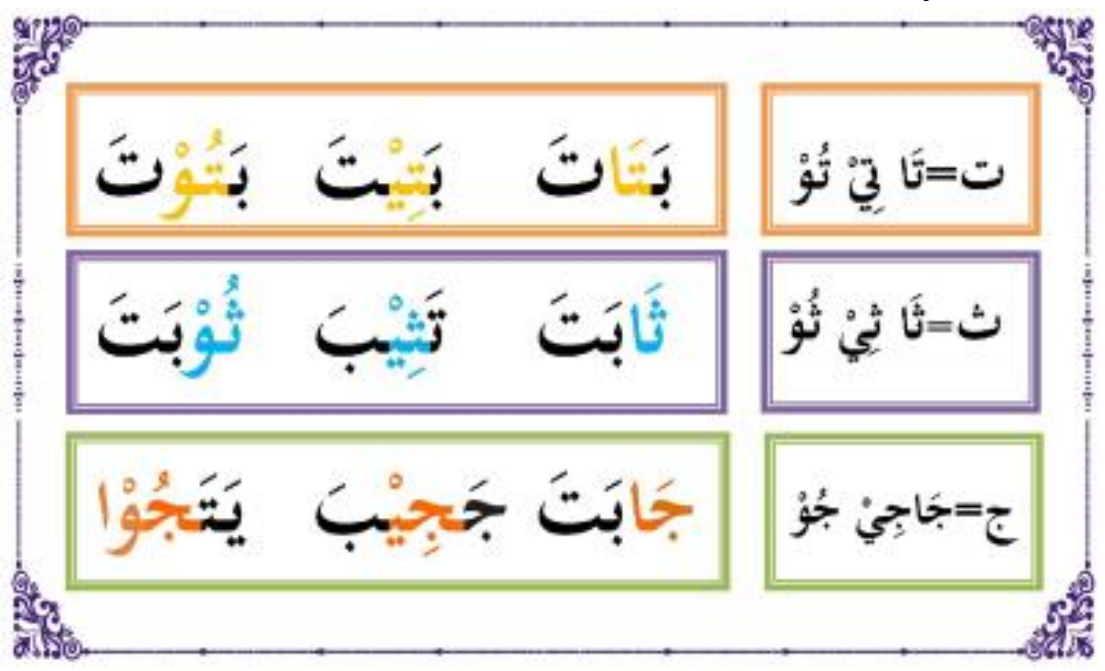

Pada akhir modul 2, peserta diberikan sebuah contoh ayat al-Quran yang

${ }^{17}$ Samsul Hidayat. Quantum, Ibid. h. 56. 
dapat dieja dengan metode Quantum Hijaiyah. Pembacaan ayat-ayat al-Quran adalah bagian dari post test modul dua dengan indikator keberhasilan; peserta sudah bisa merangkai huruf perhuruf dengan tanda baca yang utuh dengan bacaan yang benar meskipun masih perlahan-lahan. Adapun cara mengeja huruf adalah sebagai berikut; mentor bertanya tentang nama huruf, lalu peserta menyebutkan nama huruf tersebut. Kemudian mentor bertanya jenis tanda baca dan kemudian dijawab oleh peserta. Selanjutnya mentor bertanya terkait gabungan antara huruf dan tanda bacanya, lalu peserta menyebutkan pembacaan ayat tersebut secara utuh. Huruf dan tanda baca ditanya secara berurutan dan dijawab oleh peserta secara berurutan juga sampai akhir dari kalimat atau ayat.

Setelah membaca potongan ayat-ayat al-Quran peserta diberi skor nilai untuk mengetahui tingkat pengetahuan dan penguasaan peserta terhadap materi. Sesi kedua ini sangat urgen untuk memastikan bahwa peserta telah siap lanjut ke modul berikutnya. Jika pada modul 2 peserta masih banyak menghadapi ganjalan atau hambatan cara baca, maka mentor dapat melakukan review atau tes ulang terhadap huruf-huruf tertentu yang mungkin masih dibaca keliru. ${ }^{18}$

\section{Gambar 9}

Post Test Modul 2 dengan Memberi Skor Nilai Peserta



Selanjutnya pada modul ke tiga, peserta dikenalkan dengan tanda baca huruf yang menggunakan kaidah tajwid dasar. Artinya peserta sudah mulai menerapkan cara baca al-Quran sesuai dengan standar yang bahasa Arab, meskipun pada modul ini peserta belum dikenalkan dengan nama-nama tajwid tersebut. Peserta belum dikenalkan dengan nama tajwid untuk menghindari kebingungan dan materi yang menumpuk karena kebanyakan peserta masih terfokus pada cara baca huruf hijaiyah. Namun meski peserta belum dikenalkan

${ }^{18}$ Samsul Hidayat. Quantum, Ibid. h. 108. 
dengan nama-nama tajwid, seluruh contoh huruf dan tanda baca pada modul 3 sudah merupakan contoh bentuk-bentuk atau kaidah tajwid pada umumnya.

Salah satu bentuk tajwid yang diajarkan adalah Alif Lam Qomariah. Peneliti atau mentor tidak meminta peserta untuk menghafal nama tajwid, tapi cukup memberitahu nama tajwid tersebut dan cara membaca hurufnya. ${ }^{19}$ Pada sesi ini mentor menjelaskan bahwa jika ada huruf yang tidak memiliki tanda baca, maka hurufnya tidak perlu dibaca. Misalnya jika ada huruf alif tapi tanda baca lalu setelahnya ada huruf L, maka huruf alif dapat dilewatkan dan langsung saja membaca huruf setelah alif.

\section{Gambar 10}

Contoh Kaidah Tajwid Dasar Alif Lam Qomariah

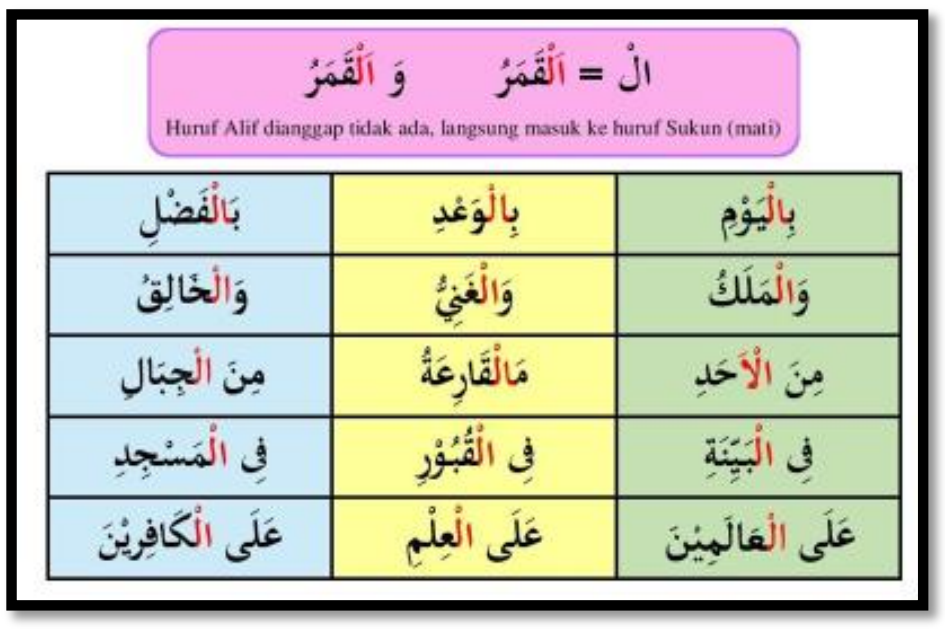

Adapun hasil dari penelitian terapan ini dapat dilihat dari pernyataan dan evaluasi pembelajaran yang dilakukan selama kegiatan. Dalam bentuk pernyataan, seluruh peserta diminta untuk memberikan testimoni atau pengakuan jujur dari mereka selama mengikuti kegiatan. Sementara dari hasil evaluasi dapat dilihat dari nilai akhir pembelajaran yang telah diisi oleh mentor.

Beberapa pernyataan atau testimoni peserta dapat dilihat dari pengakuan beberapa peserta sebagai berikut:

"Alhamdulillah, sungguh Ajaib" begitu yang dikatakan oleh ibu Yanti asal Air Hitam Menjalin, bahwa pada awalnya Yanti belum kenal satupun huruf hijaiyah. Namun setelah mengikuti pelatihan, Yanti mengaku sudah bisa membaca al-Quran dengan perlahan-lahan, meski ada yang salah dalam bacaan, tapi Yanti merasa bersyukur telah mengikuti kegiatan yang luar biasa ini. Ibu Margaretha Halimah Nurhayati (56 tahun) asal Senakin, mengakui bahwa setelah mengikuti kegiatan penerapan cara cepat baca al-Quran dengan metode Quantum Hijaiyah merasa semakin meningkat pengetahuan dan ilmu nya dan berharap dapat

${ }^{19}$ Samsul Hidayat. Quantum, Ibid, h. 98. 
menularkan ilmunya kepada para muallaf lain yang belum sempat mengikuti kegiatan tersebut.

Pada tahap pembelajaran peserta diberikan kesempatan melakukan simulasi pembelajaran, yaitu belajar antar murid dengan cara mempraktekkan bagaimana materi Quantum Hijaiyah di sampaikan seperti yang dilakukan oleh mentor.

\section{Gambar 12}

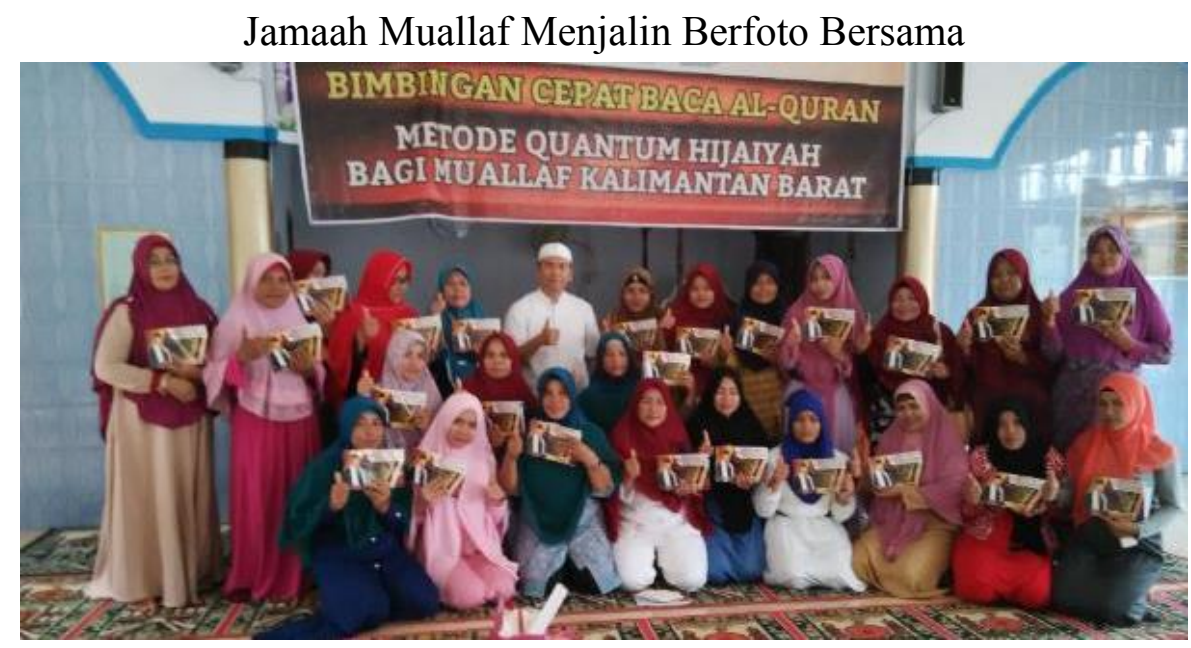

Kegiatan penerapan Metode Quantum Hijaiyah Sebagai Teknik Cepat Baca Al-Quran Pada Komunitas Muallaf Di Kalimantan Barat adalah salah satu strategi peningkatan sumber daya insani umat Islam yang baru memeluk agama Islam. Layanan keagamaan terhadap muallaf di Kalimantan Barat belum dilakukan secara sistematis dan sinergis. Beberapa pihak diharapkan dapat melakukan sinergitas seperti unsur pemerintah, lembaga dan organisasi keagamaan dan komunitas muallaf. Dengan adanya sinergitas berbagai pihak, maka persoalan buta huruf al-Quran umat Islam di Kalimantan Barat dapat teratasi.

\section{SIMPULAN/PENUTUP}

Penerapan metode Quantum Hijaiyah sebagai teknik cepat baca al-Quran telah menjadi kebutuhan urgen bagi masyarakat muslim yang terkendala dalam mempelajari ayat-ayat al-Quran. Saat ini masih ditemukan umat Islam dan terutama para muallaf yang membutuhkan pendampingan ilmu agama terutama keterampilan baca al-Quran. Fenomena ini ditunjukkan dari banyaknya pengakuan dari masyarakat terutama yang berusia dewasa bahwa mereka belum dapat membaca ayat-ayat al-Quran dengan baik dan benar. Bahkan masih banyak juga yang buta huruf atau sama sekali belum mengenal huruf-huruf hijaiyah.

Untuk itulah peran serta akademisi melalui karya atau produk pengetahuan yang dapat langsung dirasakan manfaatnya oleh masyarakat menjadi tuntutan 
masyarakat milenal, terlebih dengan kecenderungan masyarakat yang ingin serba instant, serba mudah dan serba cepat. Hal ini menuntut kecerdasan dan ketanggapan seluruh kalangan baik akademisi maupun agamawan untuk terus berinovasi dan berkreasi menciptakan produk-produk ilmu agama yang sesuai dengam kebutuhan pasar atau umat Islam.

Kementerian Agama RI melalui Intitut Agama Islam Negeri (IAIN) Pontianak hendaknya dapat terus meningkan partisipasi dan kontribusinya dalam meningkatkan indeks prestasi manusia dalam bidang sumber daya manusia yang islami melalui keterlibatan secara langsung dalam melakukan bimbingan dan layanan keagamaan dalam bentuk pendampingan atau pengabdian pada masyarakat. Semoga dengan produk ilmu akademisi seperti metode cepat baca alQuran Quantum Hijaiyah ini dapat menjadi salah satu solusi bagi rendahnya mutu baca al-Quran masyarakat dan untuk selanjutnya dapat dikembangkan dalam kajian, penelitian dan produk-produk ilmu lainnya yang inovatif dan komodifikatif.

\section{DAFTAR PUSTAKA}

Al-Maliki, Fayumi. (2011). Metode Talaqi, 3 Hari Pintar Membaca al-Quran. Jakarta: QultumMedia.

Arief, Armai. (2002). Pengantar Ilmu dan Metodologi Pendidikan Islam. Jakarta: Ciputat Pers.

Banks, Sarah. (2012). Community Based Participatory Research A Guide to Ethical Principles and Practice, Center for Social Justice and Community Action, Durham University, UK.

Hidayat, Arif. (2011). Cara Kilat Pandai Membaca Al-Qur'an. Jakarta: PT. Buku Kita.

Hidayat, Samsul (2015) Quantum Hijaiyah; Panduan Mudah dan Cepat Membaca al-Quran (19 Jam Bisa Baca al-Quran). Pontianak: IAIN Press.

(2017) Pengembangan Metode Quantum Hijaiyah Sebagai Teknik Cepat Baca al-Quran pada Masyarakat Muallaf d Masjid Muhajirin Desa Senyabang Kecamatan Balai Kabupaten Sanggau Kalimantan Barat, dalam Maju Bersama, Jurnal Pendidikan Agama Islam, Volume 9 Edisi Desember 2017.

Hine, Gregory S. C. (2013). The importance of action research in teacher 
education programs, dalam Design, develop, evaluate: The core of the learn in environment. Proceedings of the 22nd Annual Teaching Learning Forum, 7-8 February 2013. Perth: Murdoch

University. http://ctl.curtin.edu.au professional_development/conferences/t lf/tlf2013/refereed/hine.html.

Mudhar, M. Ali. (2011). Membaca al-Quran itu Mudah Metode Al-Fatah. Kalasan: Kalasan Press.

Pasick, Rena. (2010). Geraldine Oliva, MD, MPH, Ellen Goldstein, MA, Tung Nguyen, MD, dalam Paula Fleisher, MA (Ed),Community-Engaged Research with Community Based Organization, Community Engagement Program. CTSI, University of California, San Francisco.

Rosyada, Dede. (2016). Community Based Research CBR) Salah Satu Model Penelitian Akademik. http://www.uinjkt.ac.id/community-based-researchcbr-salah-satu-model-penelitian-akademik/

Rosyady, M. (1999). An-Nur, InsyaALlah dalam 2 Jam Anda Sudah Bisa Baca alQuran. Jakarta: Syiar Islam.

Rusmono (2012) Strategi Pembelajaran dengan Problem Based Learning Itu Perlu: Untuk Meningkatkan Profesionalitas Guru. Bogor: Ghalia Indonesia.

Sanjaya, Wina. (2007). Strategi Pembelajaran Berorientasi Standar Proses Pendidikan. Jakarta Kencana Prenada Media Group.

Yahya, M. Ashim. (2016). Metode Alhuda 5 Jam Bisa Baca al-Quran, Jakarta: Noura. 